\title{
PERIODONTITE EM CAPRINOS LEITEIROS ESTABULADOS
}

\author{
PERIODONTITIS IN MILCH GOATS STABLED \\ P. L. CAMPELLO ${ }^{1 *}$, S. D. AGOSTINHO ${ }^{1}$, A. C. BORSANELLI ${ }^{1}$, E. GAETTI-JARDIM JR ${ }^{2}$, \\ I. S. DUTRA ${ }^{3}$
}

\section{RESUMO}

Periodontite é a resposta inflamatória de um hospedeiro susceptível desencadeada por uma complexa microbiota, que resulta na perda de ligamentos periodontais, perda óssea e eventual perda da unidade dental. Em ruminantes a periodontite é relatada em bovinos e ovinos e está associada ao manejo da pastagem, tendo sido considerada uma das enfermidades de grande impacto econômico na pecuária brasileira nas décadas de 1970-1990 e associada à formação de pastagens em áreas de derrubada de matas e no cerrado. Nos caprinos, é raro o relato da ocorrência da doença, provavelmente pela pequena população de animais em áreas consideradas endêmicas. Diante do histórico da possível ocorrência de doença periodontal em caprinos de rebanho leiteiro de propriedade rural localizada no Estado de São Paulo e da inexistência de estudos sobre a sua etiologia, o presente estudo teve como objetivo relatar a ocorrência de periodontite em cabras leiteiras estabuladas. Foram avaliadas, por amostragem aleatória, 50 cabras com dentição permanente, de um total de 200 em lactação. Os animais, mantidos permanentemente sob estabulação, eram alimentados com silagem de milho e feno de Tifton, produzidos em área cultivada periodicamente na propriedade. Recebiam ainda ração comercial. No exame intra-bucal, com o auxílio de abridor de boca e afastador labial, pode-se verificar em pelo menos um dente incisivo, pré-molar ou molar de cada cabra em lactação a ocorrência de recessão gengival, perda de inserção de diferentes intensidades, bolsa periodontal com profundidade acima de $5 \mathrm{~mm}$, sangramento, supuração e perda dentária em 15 (30\%) dos animais examinados. Pode-se observar ainda a presença de biofilme dentário de coloração preta, com variações de intensidade entre indivíduos e dentes. O relato da ocorrência de periodontite em rebanho caprino permanentemente estabulado é inédito. Muito provavelmente esta condição sanitária tem reflexo nos resultados econômicos da atividade, na saúde e bem-estar dos animais.

PALAVRAS-CHAVE: DOENÇA PERIODONTAL. CAPRINOCULTURA LEITEIRA.

ÁREA TEMÁTICA: Doenças Infecciosas 